\author{
M.Zh. Burkeev ${ }^{1}$, J. Kreuter ${ }^{2}$, Ye.M. Tazhbayev ${ }^{1}$, L.Zh. Zhaparova ${ }^{1}$, \\ T.S. Zhumagalieva ${ }^{1}$, Zh.T. Arystanova ${ }^{1}$, D.A. Mukhanova ${ }^{1}$ \\ ${ }^{I}$ Ye.A. Buketov Karaganda State University, Kazakhstan; \\ ${ }^{2}$ Institute of Pharmaceutical Technology, Biocenter Niederursel, Johann Wolfgang Goethe University, Frankfurt, Germany \\ (E-mail: zhansaule.kz@mail.ru)

\section{Preparation, characterization and investigation of in vitro release of anti-tuberculosis drug p-amino salicylic acid based on human serum albumin}

\begin{abstract}
Nowadays the task of pharmaceutical chemistry is not only the search of the new drug preparations, but also the increase of the effectiveness of the latter by chemical modification or creation of new forms. With the aim of prolongation of the effect and decrease of single dose the possibility of immobilization of anti-tuberculosis drug p-amino salicylic acid (PASA) on human serum albumin (HSA) nanoparticles (NPs) by adsorption and incorporation methods was considered in this article. It is shown that independently of the immobilization method of the drug into polymer matrix the meanings of binding degree are very high. The study of the dependence of binding degree on drug concentration resulted in more than $95 \%$ at maximum concentrations of the added drug. As it has been expected the drug release degrees have high meanings when incorporating as well as adsorption the drug on the surface of empty nanoparticles. They are $70 \%$ and $80 \%$ respectively. Therefore the results obtained allow us to hope on prolongation of the effect of p-amino salicylic acid and decrease of single dose of the drug in tuberculosis therapy.
\end{abstract}

Keywords: Human serum albumin; p-aminosalicylic acid, anti-tuberculosis drug, nanoparticles, adsorption, immobilization, incorporation, polymer matrix.

\title{
Introduction
}

Nowadays short period of action, low selectivity and rather high toxicity are considered as the main drawbacks of drug preparations used in medicine. The results of numerous investigations have shown the possibility of disposition of these shortcomings by binding the drugs with polymers [1-3]. Promising results have been obtained when nanoencapsulating the drugs $[4,5]$ which are used for the treatment of such diseases as tuberculosis and tumor with natural and synthetic polymers [6-11]. PASA is one of the first antibiotics used in the treatment of tuberculosis and it is currently the drug required for the use in the Republic of Kazakhstan. During the time of use of the drug the resistance to tuberculosis strain has been developed and a single dose now reached ten grams. In this regard, the task of researchers is to prolong the effect of antituberculosis drug by binding it to polymer thus reducing the single dose of the drug.

One of the most widely used polymeric carriers of drugs is human serum albumin (HSA). Due to its ability to transport low molecular compounds, including different kinds of drugs into a great variety of cells, especially after conversion to NPs, it represents a unique transporting material which allows to carry drugs into certain target-organs, thus prolonging their efficiency [12-15].

In the present study the possibility of immobilization of antituberculosis drug PASA with albumin NPs by adsorption of the drug onto preliminary synthesized empty nanoparticles and incorporation of the PASA during the process of particle crosslinking will be investigated.

\section{Materials and methods}

Human serum albumin (HSA, fraction V, purity 96-99 \%, $65.000 \mathrm{Da}$ ) and glutaraldehyde $8 \%$ solution were purchased from Sigma (Steinheim, Germany). PASA were purchased from LLP «Romat» (Pavlodar Pharmaceutical Factory, Pavlodar, Kazakhstan). Solvents and all other reagents were purchased from Merck (Darmstadt, Germany). Deionized (DI) water was used throughout the study.

Empty albumin NPs have been synthesized by desolvation method according to the procedure given in $[3,12,13,15] .200 \mathrm{mg}$ of HSA were dissolved in $2 \mathrm{ml}$ of purified water and the $\mathrm{pH}$ was adjusted to $8.2-8.5$ with $0.01 \mathrm{M} \mathrm{NaOH}$. Then under constant stirring $(600 \mathrm{rpm})$ at room temperature $8 \mathrm{ml}$ of ethanol $(96 \%)$ was added $(1 \mathrm{ml} / \mathrm{min})$ using a tubing pump. After the desolvation process the particles were stabilized by the addition of an aqueous $8 \%$ glutaraldehyde solution $(1.175 \mu \mathrm{l}$ per ml HSA $)$. In order for the process to be finished, the suspension was stirred for $24 \mathrm{~h}$. The obtained nanoparticles were separated from low molecular 
components by repeated centrifugation with the Centrifuge MiniSpin Plus 14500 (Eppendorf, Hamburg, Germany) at $14500 \mathrm{rpm}$ and by washing them with water.

Adsorption of PASA onto empty nanoparticles of HSA carried out in two steps: obtaining empty nanoparticles and the subsequent binding of the drug with the polymer. Prepared solutions of the drug with concentrations of $0.16 \%, 0.32 \%, 1.0 \%, 2.0 \%$ and $4.0 \%$ were added to the solutions of empty albumin NPs obtained by above said technique and were stirred for 2 hours at room temperature. The required particle by size is separated by repeated centrifugation within 15 minutes at $14,500 \mathrm{rpm} / \mathrm{min}$ and was purified by washing with water.

The yield of NPs was determined by a microgravimetric method.

Incorporation of PASA into serum albumin was carried out at one stage by the procedure described below:

Calculated amount of PASA was added to the $2 \%$ solution of serum albumin with $\mathrm{pH} 8.0-8.5$ and was stirred for 2 hours. For the formation of NPs calculated amount of $8 \%$ solution of glutaric aldehyde was added to the drug solutions. The particles of needed sizes have been separated from low- and high molecular compounds by multiple centrifugation and washing with water.

The average particle size was measured by photon correlation spectroscopy (PCS) using a Malvern Zetasizer 3000HSA (Malvern Instruments Ltd., Malvern, UK) at a temperature of $25^{\circ} \mathrm{C}$ at a scattering angle of $90^{\circ}$. The samples were diluted 1:400 with water.

Drug content was determined by conductometric method. The measurements of electrical conductivity of solutions were performed on a Conductivity meter Type OK-102 (Hungary) № 1182 OOO «EconicsExpert» and INN/KPP 7728209000/772801001 (Moscow) using platinum electrodes and a thermostat UTU2/77 (Polanol) with thermostatic electrical cell with a volume of $25 \mathrm{ml}$.

$0.1,0.08,0.06,0.04,0.02,0.01,0.005 \mathrm{mg} / \mathrm{ml}$ drug solutions in water were prepared for a calibration curve. The quantity of unbound drug was calculated using a calibration curve.

\section{Results and discussion}

Empty HSA nanoparticles were obtained according to the technique given above [3, 12, 13, 15]. Nanoparticles with average diameter of $310 \mathrm{~nm}(\mathrm{PDI}=0.142)$ were formed.

There are two main ways of binding of drugs to HSA nanoparticles [3, 12, 13, 15]: 1) physical adsorption of drugs on the surface of preliminary prepared NPs, and 2) incorporation of drugs into the polymer matrix during particle preparation. Therefore at first PASA was bound to the polymer by adsorption of the drug on the surface of preliminary synthesized empty HSA nanoparticles. The adsorption of the drug on HSA nanoparticles has been performed with concentrations of PASA in initial solution ranging from 0.16 to $4.0 \%$. The immobilization of PASA with empty NPs has been carried out by direct mixing of corresponding solutions. Adsorption of the drug on the surface of preliminary prepared NPs led to a minor increase of the particle size $(\mathrm{d}=316 \mathrm{~nm}, \mathrm{PDI}=0.140)$.

It is necessary to note that molecules of both serum albumin (1) and PASA (2) contain carboxylic and amino groups which should lead to some effects when creating chemical bonds.

$$
\mathrm{H}_{2} \mathrm{~N}-\left[\mathrm{R}^{1}-\mathrm{NH}-\mathrm{CO}-\mathrm{R}^{2}\right]-\mathrm{COOH}
$$<smiles>Nc1ccc(C(=O)O)c(O)c1</smiles>

(2)

The binding degree of the drug with HSA nanoparticles was determined using conductivity measurements. Conductometry enables estimation of the binding of drug with polymer directly in the reaction medium without preliminary separation of nanoparticles from the solution. The quantity of unbound drug was calculated using a calibration curve. The results of the binding experiments of PASA on HSA nanoparticles are shown in Figure 1.

Increasing the concentration of PASA in solution leads to increase of binding degree with limiting meaning of $95 \%$ (Fig. 1). 


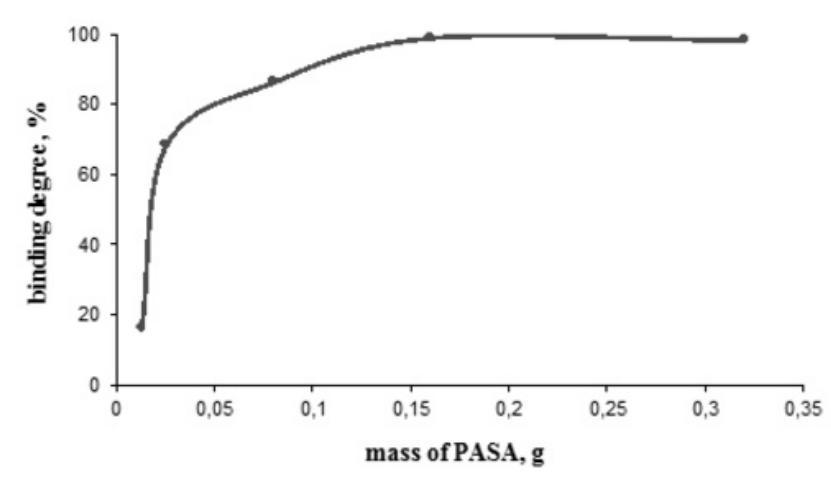

Figure 1. Dependence of binding degree on mass of PASA

This regularity correlates well with the assumption that the bond between drug and polymer was formed by ionic mechanism. The binding of the drug with HSA was investigated using photocolorimetry and viscosimetry. The results are shown in Figure 2.

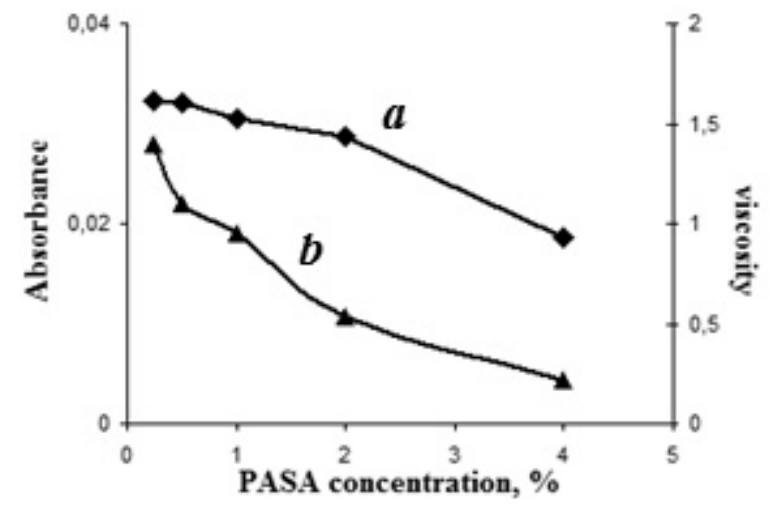

Figure 2. Dependence of viscosity $(a)$ and absorbance $(b)$ of albumin solution on concentration of PASA (using viscosimetry)

The above given assumptions are in good accordance with conducted viscosimetric measurements (Fig. 2). Decrease of viscosity of serum albumin solution is caused by suppression of polyelectrolytic effect on two directions: 1) the screening effect of amino- and carboxylic groups; 2) their chemical binding which is an advantage for the creation of novel drug preparations. The same dependence is observed from the graph of dependence of absorbance on concentration of drug added which points on compaction of polymeric particles (Fig. 2).

As a continuation of our study the kinetics of release of anti-tuberculosis drug PASA from the polymer matrix of serum albumin was investigated. Release of PASA from HSA nanoparticles produced by adsorption method was studied during the day. The results are shown in Figure 3.

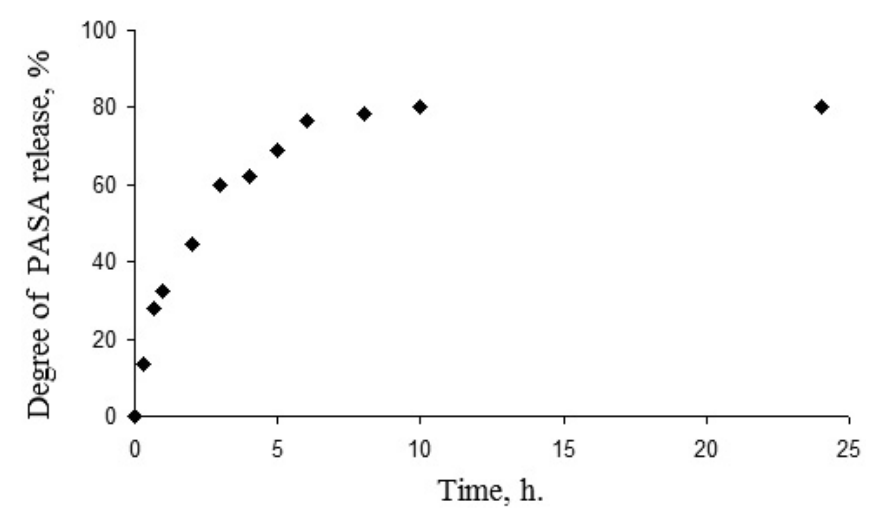

Figure 3. Drug release profile of PASA-loaded NPs (for the NPs obtained by adsorption method) 
As seen from the graph, a significant portion of the drug released into the medium during first 3 hours (about $30 \%$ per hour, about $60 \%$ in 3 hours). This is apparently because of the desorption of the drug, located on the surface of NPs. Further, there is a gradual release of PASA from nanoparticles of HSA of up to $80 \%$ of the drug. The remaining part of PASA did not release, which could be related to the structure of the crosslinked polymeric nanoparticles.

When adsorbing the drug onto the surface of NPs there is a risk of loss of some part of the drug by desorption, in this regard at the next stage we have studied the binding of the drug during particles' crosslinking.

In this case PASA was preliminarily dissolved in water solution of serum albumin and then desolvation was carried out. Average particle diameter obtained by incorporation method was $435 \mathrm{~nm}(\mathrm{PDI}=0,147)$. The concentration of the drug in initial solution was sustained as in case of adsorption. Binding degree of PASA was also determined by conductometry method (Fig. 1).

As it is seen from the graph in this case almost $100 \%$ binding was possible (Fig. 1).

As in this case the drug is incorporated inside of NPs the curves of dependence of viscosity and absorbance are opposite to the ones obtained by adsorption method (Fig. 4).

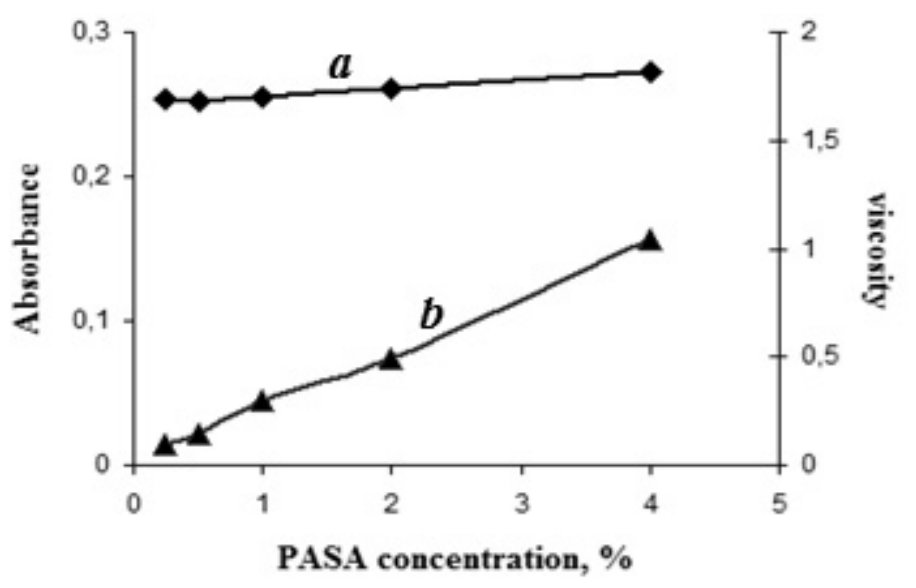

Figure 4. Dependence of viscosity $(a)$ and absorbance $(b)$ of albumin solution on concentration of PASA (using photocolorimetry)

Because of the presence of ionogenic groups on the surface of NPs this dependence tends to increase due to no suppression of polyelectrolytic effect.

Then the degree of drug release from the matrix HSA nanoparticles obtained by incorporation method has been studied, of which the results are shown in Figure 5.

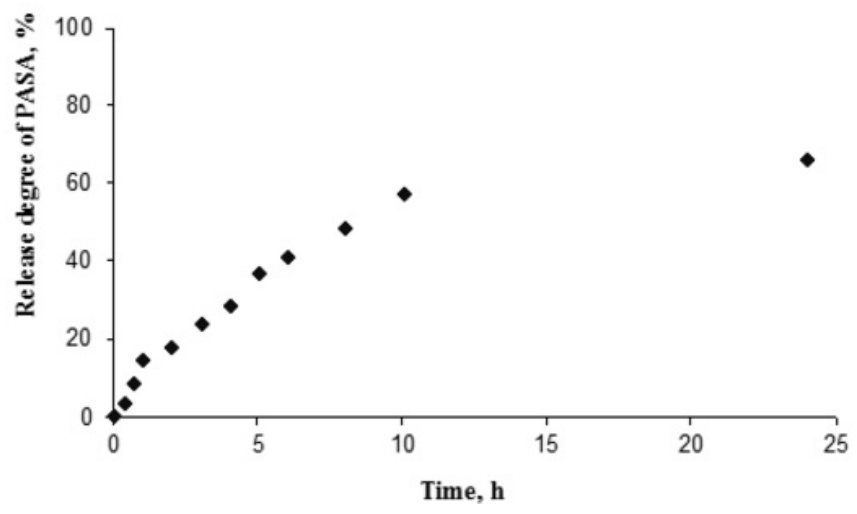

Figure 5. Drug release profile of PASA-loaded NPs (for the NPs obtained by incorporation method)

The graph shows that, as compared with the adsorption method in the case of incorporation a sustained release of PASA is observed. It is explained by release of the drug located inside the NPs. Thus, about $15 \%$ of the drug released per hour, and only $24 \%$ of PASA for $3 \mathrm{~h}$. While the observation of the kinetics of drug release from NPs obtained by adsorption method, 2 times more of PASA released during the same period of time. Also the yield of NPs loaded with drug was determined (Table). 
Yield of HSA nanoparticles loaded with PASA

\begin{tabular}{|c|c|c|}
\hline \multirow{2}{*}{$\begin{array}{c}\text { Drug content } \\
\text { in initial solution, } \mathrm{g}\end{array}$} & \multicolumn{2}{|c|}{ The yield of nanoparticles determined by microgravimetry, \% } \\
\cline { 2 - 3 } & Obtained by adsorption & Obtained by incorporation \\
\hline 0.0125 & 92 & 92 \\
\hline 0.025 & 43 & 89 \\
\hline 0.08 & 41 & 55 \\
\hline 0.16 & 13 & 10 \\
\hline 0.32 & 67 & 35 \\
\hline
\end{tabular}

In both cases the particle yields were high. The tendency of decreasing of the yield of NPs reaching a minimum with increasing of drug concentration was observed (Table 1). With the last sample high yield of NPs has been achieved.

\section{Conclusion}

Thus, in this work the possibility of obtaining polymer carriers of nanometric sizes based on HSA for the transport of anti-tuberculosis drug PASA has been shown. The results obtained have demonstrated that the loading of HSA with PASA by both adsorption and incorporation methods enables synthesizing NPs with satisfactory characteristics, high values of the binding degree and high nanoparticle yield. According to the results of the study on drug release it can be concluded that slower drug release is observed when immobilization of PASA by incorporation method in NPs. However, despite the relatively rapid release of PASA from HSA nanoparticles obtained by the adsorption method, these polymeric NPs can also be effectively used as drug delivery systems for anti-tuberculosis drug PASA.

\section{References}

1 Платэ Н.А. Физиологически активные полимеры и макромолекулярные терапевтические системы / Н.А. Платэ, А.Е. Васильев // Высокомол. соед. Сер. А. - 1982. - Т. 24, № 4. - С. 675-695.

2 Кирш Ю.Э. Лекарственные композиции продленного действия на полимерной основе: состав, строение и формы применения (обзор) / Ю.Э. Кирш // Хим.-фарм. журн. - 1985. — № 9. — С. 1105-1111.

3 Kreuter J. Nanoparticles // Colloidal Drug Delivery Systems / Ed. Dekker M.— New York, 1994. — P. $219-342$.

4 Шварц И.Ш. Биоразлагаемые наночастицы и нанокапсулы - носители лекарственных средств с контролируемыми свойствами / И.Ш. Шварц, А.П. Титов, А.Ю. Васильев // Актуальные проблемы создания рецептур с желаемыми биофармацевтическими свойствами: Всесоюзн. науч.-техн. конф. (24-26 окт. 1989 г.). — Харьков, 1989. — С. 141.

5 Сметанкина О.Н. Препараты пролонгированного действия на основе макромолекулярных носителей / О.Н. Сметанкина, Т.В. Приходько, Я.А. Турко // Биотехнология. Теория и практика. — 2002. — № 3. — C. 89-97.

6 Brasseur F. Actinomycin D adsorbed on polymethylmethacrylate nanoparticles: an increased efficiency against an experimental tumor / F. Brasseur, P. Couvreur, B. Kante, L. Deckers-Passau, M. Roland, C. Deckers et al. // Eur. J. Cancer. 1980. Vol. 16. - P. 1441-1445.

7 Couvreur P. Controlled drug delivery with nanoparticles: current possibilities and future trends / P. Couvreur, C. Dubernet, F. Paisieux // Eur. J. Pharm. and Biopharm. - 1995. - Vol. 41, No. 1. - P. 2-13.

8 Скидан И. Повышение антибактериальной активности рифампицина в отношении внутриклеточных инфекций с помощью биодеградируемых наночастиц / И. Скидан, С. Гельперина, С. Северин, А. Гуляев // Антибиотики и химиотерапия. - 2003. - Т. 48, № 1. - C. 23-26.

9 Гельперина С.Э. Исследование наносомальной лекарственной формы доксорубицина / С.Э. Гельперина, 3.С. Смирнова, А.С. Халанский, И.Н. Скидан, С.Е. Северин, Й. Кройтер // Рос. биотерапевт. журн. — 2004. — Т. 3. — С. 5664.

10 Оганесян Е.А. Разработка и изучение наносомальной лекарственной формы рифампицина / Е.А. Оганесян, А.П. Будько, О.О. Максименко, Ю.В. Стукалов, И.И. Любимов, С.Ф. Бикетов, П.Г. Свешников, Л.Б. Хейфец, С.Э. Гельперина // Антибиотики и химиотерапия. - 2005. - Т. 50. - С. 15-19.

11 Шипуло Е.В. Получение и исследование наносомальной формы моксифлоксацина на основе полибутилцианоакрилата / Е.В. Шипуло, И.И. Любимов, О.О. Максименко и др. // Хим.-фарм. журн. — 2008. — Т. 42, № 3. — С. $43-47$.

12 Langer K. Optimization of the preparation process for human serum albumin (HSA) nanoparticles / K. Langer, S. Balthasar, V. Vogel, N. Dinauer, H. von Briesen, et al. // Int. J. Pharm. — 2003. — Vol. 257. — P. 169-180.

13 Maeda H. Tumor vascular permeability and the EPR effect in macromolecular therapeutics: a review / H. Maeda, J. Wu, T. Sawa, Y. Matsumura, K. Hori // J. Control Release. — 2000. - Vol. 65. — P. 271-284.

14 Адекенов С.М. Арглабин - противоопухолевое средство из полыни гладкой (Artemisia glabella Kar. Et Kir.) / С.М. Адекенов // Рос. биотерапевт. журн. — 2002. — Т. 1, № 2. - С. 5-7. 
15 Dreis S., Rothweiler F., Michaelis M., Cinatl J., Jr., Kreuter J., Langer K. Preparation, characterisation and maintenance of drug efficacy of doxorubicin-loaded human serum albumin (HSA) nanoparticles / Dreis S., Rothweiler F., Michaelis M., Cinatl J., Jr., Kreuter J., Langer K. // Int. J. Pharm. — 2007. — Vol. 341, No. 1-2. — P. 207-214.

М.Ж. Бүркеев, Ж. Кройтер, Е.М. Тажбаев, Л.Ж. Жаппарова, Т.С. Жумагалиева, Ж.Т. Арыстанова, Д.А. Муханова

\title{
Адам сарысулы альбумин негізіндегі туберкулезге қарсы \\ n-аминосалицил қышқылы препаратының алынуы, сипаттамасы және босап шығуын in vitro зерттеу
}

\begin{abstract}
Қазіргі таңдағы фармацевтикалық химияның басты міндеттерінің бірі жаңа дәрілік препараттарды іздеу ғана емес, сонымен қатар жаңа үлгіні жасап шығару немесе химиялық түрлендіру арқылы оның тиімділігін арттыру болып табылады. Бір реттік қабылдау мөлшерін азайту және әсерін ұзарту мақсатында бұл мақалада туберкулезге қарсы препарат пара-аминосалицил қышқылын адам сарысу альбуминнің нанобөлшектеріне енгізу және адсорбция әдісімен иммобилизациялау мүмкіндігі қарастырылған. Дәрілік затты полимер матрицасына иммобилизациялау әдісінен тәуелсіз байланысу дәрежесінің мәндері жоғары болатыны көрсетілген. Байланысу дәрежесінің дәрілік зат концентрациясынан тәуелділігін зерттеу барысында дәрілік заттың максималды концентрациясында $95 \%$ жоғары мәнді көрсететіндігі анықталды. Ал препаратты бос нанобөлшектердің бетіне енгізу және адсорбция әдісі арқылы иммобилизациялау дәрілік заттың босап шығу дәрежесінің жоғары мәндеріне ие болды. Олар сәйкесінше 70 және 80 \% құрады. Сол себепті алынған нәтижелер парааминосалицил қышқылының туберкулезді емдеу барысында пролонгациялық әсер беретінін және бір реттік қабылдау мөлшерін азайтатынын дәлелдеді.
\end{abstract}

Кілт сөздер: адам сарысу альбумині, пара-аминосалицил қышқылы, туберкулезге қарсы препарат, нанобөлшектер, адсорбция, иммобилизация, енгізу, полимер матрицасы.

М.Ж. Буркеев, Ж. Кройтер, Е.М. Тажбаев, Л.Ж. Жаппарова, Т.С. Жумагалиева, Ж.Т. Арыстанова, Д.А. Муханова

\section{Получение, характеристика и исследование высвобождения in vitro противотуберкулезного препарата $\boldsymbol{n}$-аминосалициловой кислоты на основе человеческого сывороточного альбумина}

\begin{abstract}
В настоящее время задачей фармацевтической химии является не только поиск новых лекарственных препаратов, но и повышение эффективности действия препарата путем химической модификации или создания новых форм. С целью продления эффекта и уменьшения разовой дозы в этой статье была рассмотрена возможность иммобилизации лекарственного средства против туберкулеза $-n$-аминосалициловой кислоты (ПАСК) - на наночастицу человеческого сывороточного альбумина методом адсорбции и включения. Показано, что, независимо от способа иммобилизации лекарственного средства в полимерную матрицу, значения степени связывания очень велики. Изучение зависимости степени связывания от концентрации лекарственного средства приводило к более чем 95 \% при максимальных концентрациях добавленного лекарственного средства. Как и ожидалось, степени высвобождения лекарственного средства имеют высокие значения при включении и адсорбции препарата на поверхности пустых наночастиц. Они составляют 70 и 80 \% соответственно. По этой причине полученные результаты позволяют надеяться на пролонгированное действие $n$-аминосалициловой кислоты и снижение разовой дозы препарата при лечении туберкулеза.
\end{abstract}

Ключевые слова: сывороточный альбумин человека, $n$-аминосалициловая кислота, противотуберкулезный препарат, наночастицы, адсорбция, иммобилизация, включение, полимерная матрица.

\section{References}

1 Plate, N.A., \& Vasilyev, A.E. (1982). Fiziolohicheski aktivnye polimery i makromolekuliarnye terapevticheskie sistemy [Physiologically active polymers and macromolecular therapeutic systems]. Vysokomolekuliarnye soedineniia. Seriia A - Highmolecular compounds. Series A., 24, 4, 675-695 [in Russian].

2 Kirsch, Yu.E. (1985). Lekarstvennye kompozitsii prodlennoho deistviia na polimernoi osnove: sostav, stroenie i formy primeneniia (obzor) [Medicinal compositions of extended action on a polymer basis: composition, structure and forms of application (review)]. Khimiko-farmatsevticheskii zhurnal - Chem.-pharm. journal, 9, 1105-1111. 
3 Kreuter, J. (1994). Nanoparticles. Colloidal Drug Delivery Systems (M. Dekker Eds.), New York.

4 Schwartz, I.Sh., Titov, A.P., \& Vasiliev, A.Yu. (1989). Biorazlagaemye nanochastitsy i nanokapsuly - nositeli lekarstvennykh sredstv s kontroliruemymi svoistvami [Biodegradable nanoparticles and nanocapsules — carriers of drugs with controlled properties] Proceedings from: Actual problems of creating recipes with desired biopharmaceutical properties: Vsesoiuznaia nauchno-tekhnicheskaia konferentsiia (24-26 oktiabria 1989 hoda) - All-Union scientific and technical conference. (p. 141). Kharkov.

5 Smetankina, O.N., Prikhodko, T.V., \& Turko, Ya.A. (2002). Preparaty prolonhirovannoho deistviia na osnove makromolekuliarnykh nositelei [Long-acting drugs based on macromolecular carriers]. Biotekhnolohiia. Teoriia i praktika - Biotechnology. Theory and practice, 3, 89-97.

6 Brasseur, F., Couvreur, P., Kante, B., Deckers-Passau, L., Roland, M., \& Deckers, C., et al. (1980). Actinomycin D adsorbed on polymethylmethacrylate nanoparticles: an increased efficiency against an experimental tumor. Eur. J. Cancer, 16, 1441-1445.

7 Couvreur, P., Dubernet, C., \& Paisieux, F. (1995). Controlled drug delivery with nanoparticles: current possibilities and future trends. Eur. J. Pharm. and Biopharm., 41, 1, 2-13.

8 Skidan, I., Gelperina, S., Severin, S., \& Gulyaev, A. (2003). Povyshenie antibakterialnoi aktivnosti rifampitsina v otnoshenii vnutrikletochnykh infektsii s pomoshchiu biodehradiruemykh nanochastits [Increase of antibacterial activity of rifampicin against intracellular infections with biodegradable nanoparticles]. Antibiotiki i khimioterapiia - Antibiotics and chemotherapy, 48, 1, 23 -26.

9 Gelperina, S.E., Smirnova, Z.S., Khalansky, A.S., Skidan, I.N., Severin, S.E., \& Kroyter, J. (2004). Issledovanie nanosomalnoi lekarstvennoi formy doksorubitsina [Study of the nanosomal dosage form of doxorubicin]. Rossiiskii bioterapevticheskii zhurnal - Rus. biotherapist. journal, 3, 56-64.

10 Oganesyan, E.A., Budko, A.P., Maksimenko, O.O., Stukalov, Yu.V., Lyubimov, I.I., \& Biketov, S.F., et al. (2005). Razrabotka i izuchenie nanosomalnoi lekarstvennoi formy rifampitsina [Development and study of nanosomal drug form of rifampicin]. Antibiotiki i khimioterapiia - Antibiotics and chemotherapy, 50, 15-19.

11 Shipulo, E.V., Lyubimov, I.I., \& Maksimenko, O.O., et al. (2008). Poluchenie i issledovanie nanosomalnoi formy moksifloksatsina na osnove polibutiltsianoakrilata [Preparation and investigation of the nanosomal form of moxifloxacin based on polybutylcyanoacrylate]. Khimiko-farmatsevticheskii zhurnal - Chemical-Pharmaceutical Journal, 42, 3, 43-47.

12 Langer, K., Balthasar, S., Vogel, V., Dinauer, N., von Briesen, H., et al. (2003). Optimization of the preparation process for human serum albumin (HSA) nanoparticles. Int. J. Pharm., 257, 169-180.

13 Maeda, H., Wu, J., Sawa, T., Matsumura, Y., \& Hori, K. (2000). Tumor vascular permeability and the EPR effect in macromolecular therapeutics: a review. J. Control Release, 65, 271-284.

14 Adekenov, S.M. (2002). Arglabin — protivoopukholevoe sredstvo iz polyni gladkoi (Artemisia glabella Kar. Et Kir.) 「Arglabin - antitumor agent from wormwood smooth (Artemisia glabella Kar. Et Kir.)]. Rossiiskii bioterapevticheskii zhurnal Russian biotherapeutic Journal, 1, 2, 5-7.

15 Dreis, S., Rothweiler, F., Michaelis, M., Cinatl, J. Jr., Kreuter, J., \& Langer, K. (2007). Preparation, characterisation and maintenance of drug efficacy of doxorubicin-loaded human serum albumin (HSA) nanoparticles. Int. J. Pharm., 341, 1-2, $207-214$. 